\title{
EXPERIMENTAL STUDY ON HEATING OPERATION MODE USING BUILDING MASS FOR THERMAL STORAGE AND SYSTEM COEFFICIENT OF PERFORMANCE OF OUTSIDE INSULATION BUILDING
}

\author{
三浦寿幸 — $* 1$ \\ キーワード : \\ 外断熱建物，躯体蓄熱，暖房運転方法，システム成績係数
}

Keywords:

Outside insulation building, Thermal storage in building mass, Heating operation mode, Coefficient of performance of the total heating system
Toshiyuki MIURA —— $* 1$

This paper describes the experimental result of heating operation mode using building mass for thermal storage to make use of a stability at room temperature of the outside insulation building. As heat load per hour of this building was reduced by extension of heating operation time, so the hot water temperature produced by a heat pump and the supply air temperature for heating could be set lower than usual operation. As a result, the heat load per day didn't so increase and the coefficient of performance of the total heating system were on an equality with usual operation.

\section{1.はじめに}

外断熱によって断熱性を高めた建物は暖房停止後の室温低下が小 さく、1 日の積算熱負荷が暖房運転時間の長さに左右されにくくな る。著者は 9 時間暖房を前提に設計された外断熱建物の空調設備を 利用して 9 時間暖房と 16 時間暖房および全日暖房との比較実験を 試み、この点についての検証を行った ${ }^{1)}$ 。さらに、暖房時間を延長 することで単位時間あたりの熱負荷が小さくなるため、空調給気温 度の低い低温暖房に移行し、上下温度差の小さな居住性の高い温熱 環境が形成されることを確かめた。しかし、暖房運転時間の延長に 伴いポンプやファンの搬送動力が増加することが問題点として挙げ られた。このような時間延長運転の搬送動力の増加をできるだけ抑 える方法として水方式が考えられるが、配管埋設型の躯体蓄熱暖冷 房システムとその簡易予測制御について菊田、絵内らが数值解析に より検討を行っている2)。

本報では引き続き空気方式について、前述の外断熱建物の空調設 備改修後に空気熱源ヒートポンプでつくる温水温度を低めに設定し た時間延長暖房運転を試み、熱源効率の向上によって搬送動力の増 加を補う方法について検討した結果を示す。

\section{2. 実験対象建物および空調設備の概要}

表 1 に建物及び改修後の空調設備の概要、図 1 に配管系統図を示 す。建物は RC 造 6 階建で、外壁は外断熱構造、空は複層ガラスであ

る。電力会社の安価な夜間電力の躯体蓄熱利用を前提に空調設備の 改修を 2006 年に行った。電力会社による躯体蓄熱は氷蓄熱との併用 が条件となっているため、熱源設備や天井裏ダクトの改修はその方 式に従っている。氷蓄熱ユニット（以後、HP 蓄熱ユニットと呼ぶ）

\section{表 1 建物及び空調設備の概要}

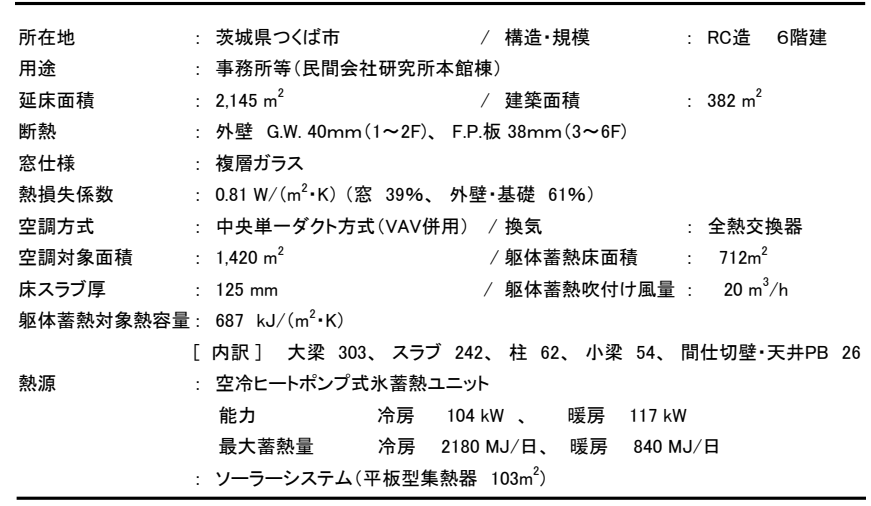

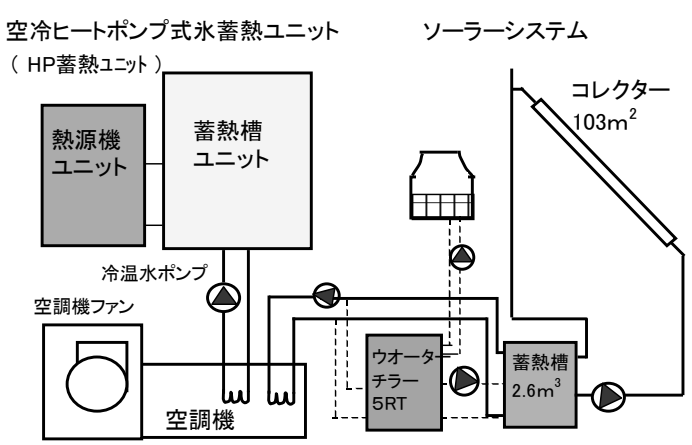

図 1 配管系統図

は空気熱源ヒートポンプ式で、最大蓄熱量が冷房 2, 180MJ/日に対し て暖房は温水蓄熱となるため $840 \mathrm{MJ} /$ 日と相対的に小さくなるが、夜 間電力利用の観点から冬季の躯体蓄熱はその不足分を補う意味で も有効と考えられる。本建物の空調対象面積は $1,412 \mathrm{~m}^{2}$ で、このう

\footnotetext{
筑波技術大学産業技術学部 教授・博士 (工学) 
ち躯体蓄熱は 3〜 階の床 $712 \mathrm{~m}^{2}$ を対象としており、蓄熱方法はスラ ブ吹付け方式である。また、他の熱源として空調機の専用コイルに 冷温水を供給する冷暖房専用のソーラーシステムを有している。

空調方式は中央単一ダクト方式で、改修では蓄熱対象となる床下 の天井裏ダクトを日中室内に泠温風を吹出す系統と夜間にスラブへ 冷温風を吹付ける系統とに分け、それらを切替えダンパーで制御可 能とした。天井裏ダクト系統図の一例を図 2 に示す。図面をもとに 算出した蓄熱対象となるスラブや梁 $(\mathrm{RC})$ 等の熱容量は $687 \mathrm{~kJ} /\left(\mathrm{m}^{2} \mathrm{~K}\right)$ であり、吹付け口数は 4.7 個 $/ 100 \mathrm{~m}^{2}$ 、吹付け風量は $20 \mathrm{~m}^{3} /\left(\mathrm{m}^{2} \mathrm{~h}\right)$ とし た。

\section{3. 実験概要}

温度等の実測は 4 階の執務室と床スラブ及び 3 階の天井裏を中心 に行った。図 3 〜 5 にセンサー設置位置を示寸。床スラブは測定点 1 力所につき、高さ方向に熱電対が上中下 3 点埋設されており、3 階天井裏内部には各測定点の中央の高さに熱電対が設置されている。 さらに建物屋上で外気温度と日射量を測定するとともに、空調機風 量、給気温度、建物全体のコイル供給熱量、熱源及び搬送設備の消 費電力量を測定した注1)。

表 2 に空調設備の実験運転条件、図 6 に運転スケジュールを示す。 MODE-01 はこの建物で通常行っている運転方法で、電力会社の躯体 蓄熱を $1 ： 00$ から $5: 00$ まで 4 時間行い、暖房時間は $8: 00 〜 17$ : 30 である。また、氷蓄熱槽内に温水蓄熱を $5: 00$ から蓄熱完了まで (最大 3 時間、蓄熱完了時温水温度 $55^{\circ} \mathrm{C}$ ) 行い、利用温度差は $10^{\circ} \mathrm{C}$ とし、それ以下で追掛運転となる。日中の空調時 (MAX) 及び躯体蓄 熱時（固定）の空調機送風温度設定は $35^{\circ} \mathrm{C}$ であ。MODE-02、03 は 躯体蓄熱運転時間をMODE-01 と同じとし、暖房運転時間をそれぞれ $22 ： 00$ 、翌日 $1 ： 00$ まで延長するとともに、温水蓄熱槽の蓄熱完了 温度を $50^{\circ} \mathrm{C} 、 45^{\circ} \mathrm{C}$ (利用温度差は共に $10^{\circ} \mathrm{C}$ ) に下げ、空調機送風温 度設定を $32^{\circ} \mathrm{C} 、 30^{\circ} \mathrm{C}$ と相対的に低く設定した。また、暖房時設定室 温 $\left(22^{\circ} \mathrm{C}\right)$ 及び新鮮外気取入れ時間、ソーラーシステムの蓄熱槽利 用下限温度は 3 つ運転方法で同じとした。

\section{4. 実験結果}

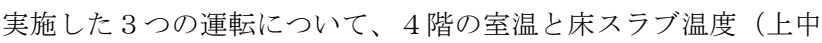
下 3 点の平均值で整理)、3 階の天井裏空気温度、及び消費エネルギ 一等の空調システム稼動状況の経時変化を図 7 に示す。この実験に 先立って改修後の空調設備による躯体蓄熱を行う場合の運転 (MODE-01) と行わない場合との比較実測を行い、躯体蓄熱によって コイル負荷が昼夜に平均化されて単位時間当たりの負荷が抑えられ る傾向となることを確認した ${ }^{3)}$ 。図 7 より、躯体蓄熱を行い、か

\section{表 2 実験運転条件}

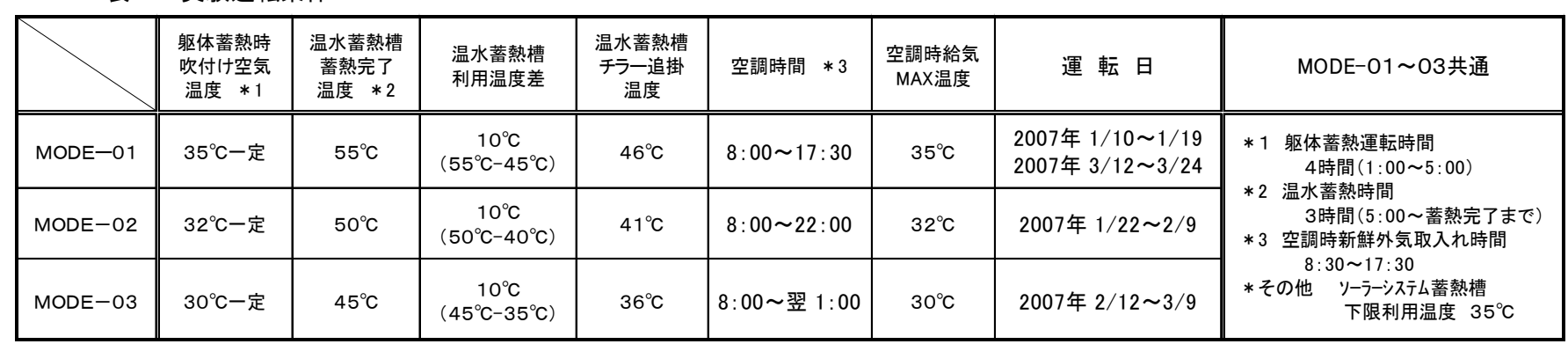

つ暖房時間を延長した MODE-02、03では暖房時間の長さに応じてさ らにその傾向が顕著になることがわかる。また、躯体蓄熱時及び暖 房運転時の空調機送風温度は MODE-01〜03 のいずれもほぼ設定通り となっていることが確認できる。暖房運転時の空調機給気風量の制 御はVAV 方式である。晴れた日の日中は室温がやや上昇傾向にある が、MOD0-01、02 の暖房停止後の室温低下は小さく、MOD0-03 を含め た 3 つ運転の室温、床スラブ温度はほぼ同様の傾向になっている ことがわかる注2)。

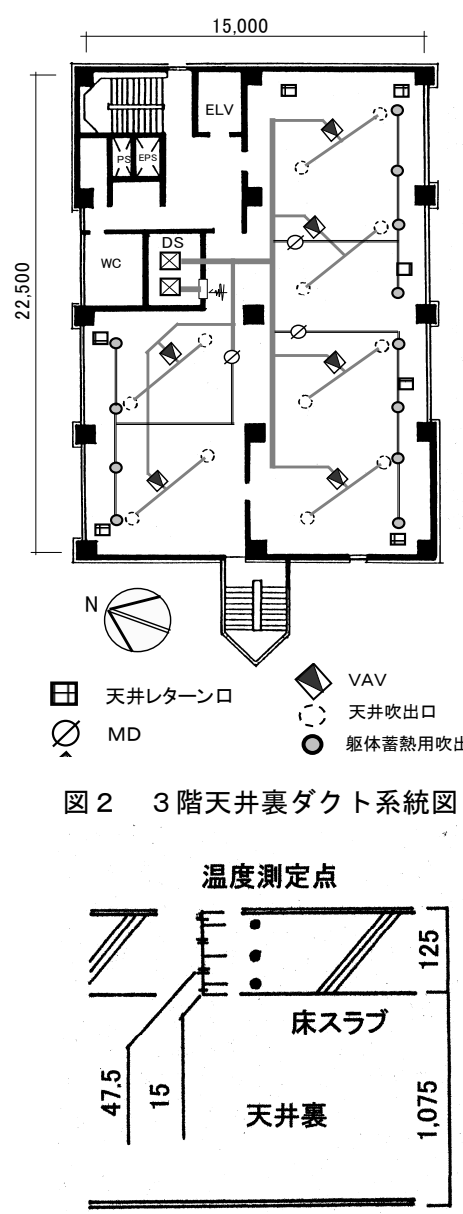

図 4 床スラブ内の測定点

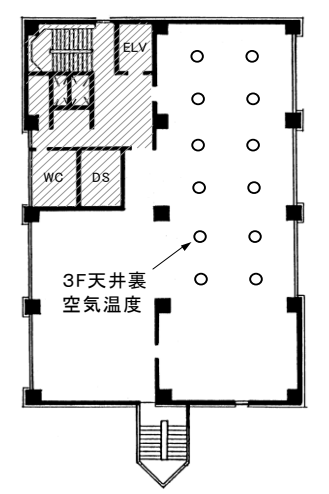

図 53 階天井裏の測定点

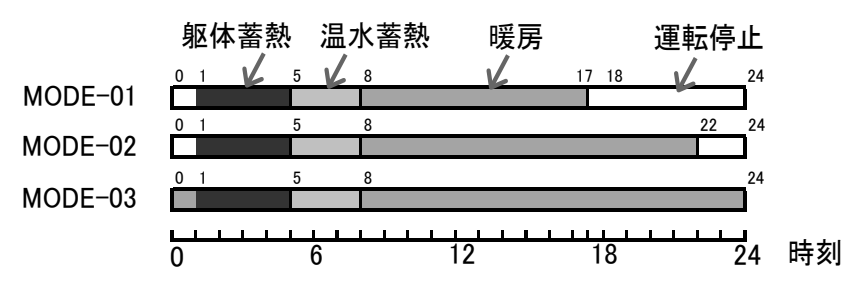

図 6 空調運転スケジュール

図 34 階室内の測定点

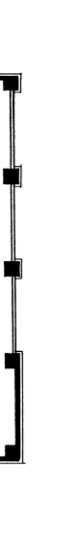


MODE-01

MODE-02

MODE-03

1 月 17 日（水） 1 月 18 日（木）

1月23日（火） 1 月 24 日（水）

2 月 20 日（火） 2 月 21 日（水）
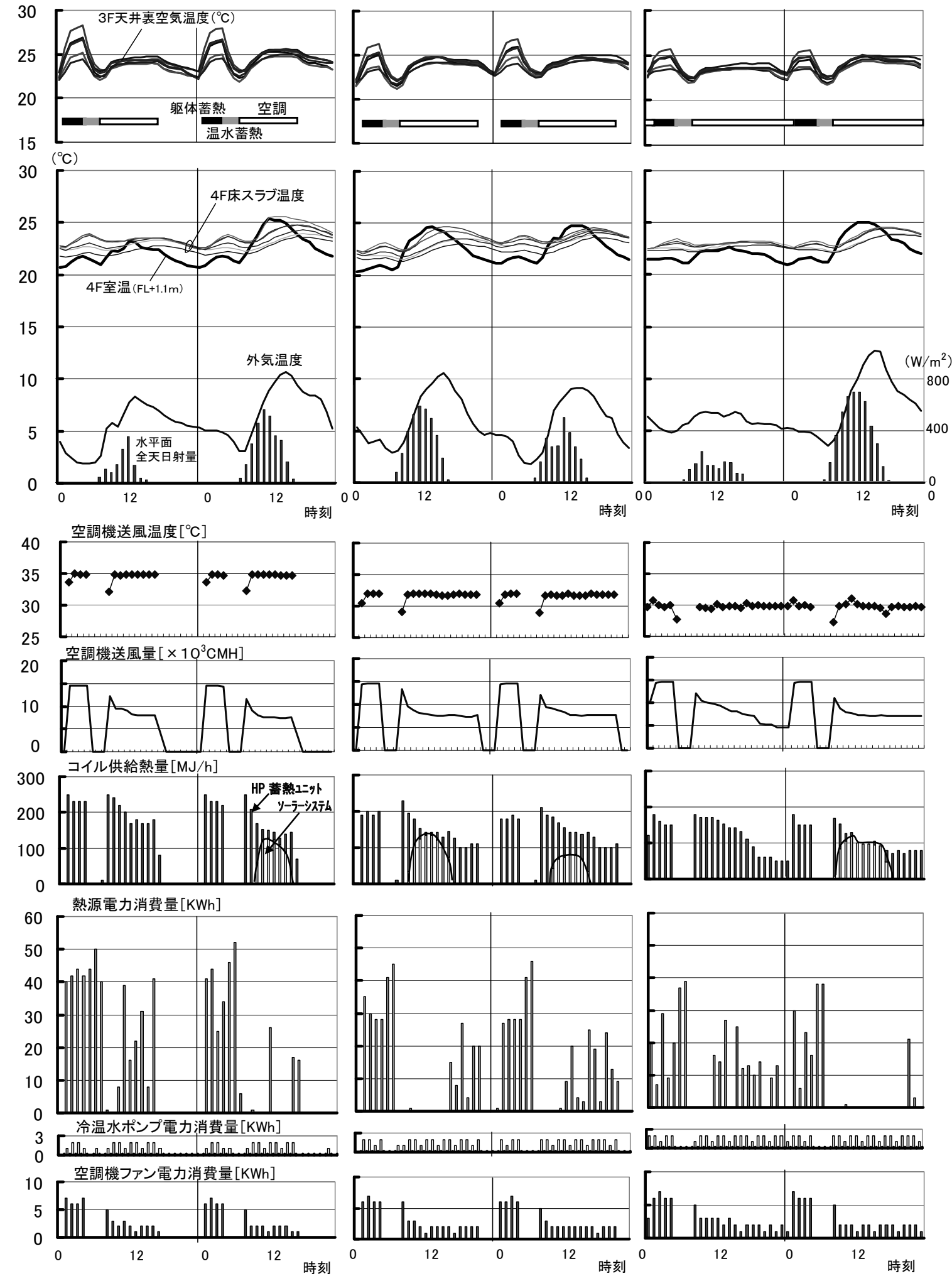

図 7 各運転方法による温度、消費エネルギー等の経時変化

図 8 に日平均外気温度と日積算コイル供給熱量（HP 蓄熱ユニットナリー ラー) との関係を示す。MODE-01 と運転時間を延長した MODE-02、03 のコイル供給熱量にさほど違いはみられない。

図 9 に日平均外気温度（HP 蓄熱ユニ外稼動時間帯）とシステム COP （熱源）との関係を運転方法別に示寸。ここで、システム COP（熱
源）は入力側が HP 蓄熱ュシト日積算消費電力量の 2 次エネルギー換算 值、出力側が HP 蓄熱卫ニッによる日積算コイル供給熱量である注 3 )。 これより、同程度の外気条件のもとでは、蓄熱槽内の温水温度を低 く設定した MODE-02、03 の COP が向上していることが確認できる。 しかし、MODE-02、03 は暖房運転時間を延長しているので、冷温水 
ポンプと空調機ファンの電力量が増加傾向となっていることを考慮 する必要がある。そこで、システム $\mathrm{COP}$ (熱源) の入力側に冷温水 ポンプと空調機ファンの電力消費量 2 次エネルギー換算值を加算し て算出される值をシステム COP（熱源十搬送）と定義し、それと日 平均外気温度（HP 蓄熱工ニ榢動時間帯）との関係を整理して図 10 に示す。これより、MODE-02、03 のシステム COP（熱源十搬送）は MODE-01 に比べてやや高め、もしくは同等となっていることがわか り、エネルギー効率の面からもこうした運転方法が不利にはならな いことが確認できる。なお、実験期間全体で MODE-01 03 の平均外 気温（HP 蓄熱ユニット稼働時間帯）は $5.0^{\circ} \mathrm{C} 、 5.1^{\circ} \mathrm{C} 、 5.3^{\circ} \mathrm{C}$ であっ たが、これに対するシステム $\mathrm{COP}$ (熱源+搬送) はそれぞれ 1.27、1.32、 1. 35 となった。また、MODE-02、03 は躯体蓄熱に利用寸る夜間電力 量が減少傾向となって運用コスト的にはやや不利になるが、躯体蓄 熱時間を長くするといった対応が考えられる。

\section{5. まとめ}

外断熱建物の安定した室温を生かす方法として、暖房運転時間の 延長により単位時間あたりの熱負荷を小さくし、ヒートポンプでつ くる温水温度及び空調機送風温度を通常よりも低い設定とする運転 を試行した。その結果、熱源の成績係数が向上し、暖房運転時間の 延長に伴う搬送動力の増加分をほぼ補えることを実験的に明らかに した。

夜間電力利用を念頭に蓄熱時の温度差を大きくとった短時間での 躯体蓄熱も一つの方法ではあるが、時間延長運転を併用して小さな 温度差でゆっくりと蓄熱し、設備容量の縮小や太陽熱、排熱などの 低落差エネルギーの有効利用を図る躯体蓄熱が外断熱の熱特性に適 した方法と考える。

\section{謝辞}

実験に際してご協力頂いた戸田建設株栗木茂氏、戸田ビルパート ナーズ株桜井重雄氏をはじめ、関係各位に謝意を表する。

\section{注}

注 1) 空調設備名りの測定は、空調制御及び監視用として各所に設置した風量計（ピ トー管利用)、温度センサー、カロリーメーター、電力量計を用いて行った。

注 2) 図 7 の各実験日における執務時間帯平均での室内上下温度差（FL+1.1m と FL

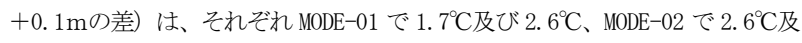

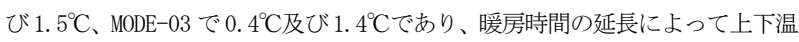
度差が縮小され、居住性が向上寸ることも確認できた。

注 3 ) システム COP (熱源) の算定はソーラーシステムを除外して行った。この場合、 1 日の日射量 (ソーラーシステム供給熱量) の違いによる追挂運転時間の差の システム COP (熱源) 一及ぼす影響の程度が気になるところだが、MODE-01〜03 の各実験期間における雨天、量天、晴れ日の頻度にさほど違いはないこと、追 挂運転時間が増える雨天や晴天日の日中の外気温度はさほど上昇しないこと が多いことからその影響は小さいと考えられる。なお、各 MODE の実験期間に おけるソーラーシステム供給熱量の傾向（110～400MJ/日、(2)401～800 MJ/日、 (3) $801 〜 1200 \mathrm{NJ} /$ 日、 (4) $1201 \mathrm{MJ} /$ 日〜の出現割合) は、MODE-01（13\%、37\%、 $50 \% 、 0 \%) 、$ MODE $-02(8 \% 、 38 \% 、 54 \% 、 0 \%) 、$ MODE $-03(16 \% 、 17 \% 、 61 \%$ 、 6\%) であった。

\section{文献}

1） 三浦寿幸，小池浄一，荒谷登 : 外断熱の熱特性を生かした躯体蓄熱空調システム に関する研究 一天井チャンバーを利用した躯体蓄熱方式 -, 日本建築学会 計画系論文集 No. 526, pp. 25-30, 1999.12

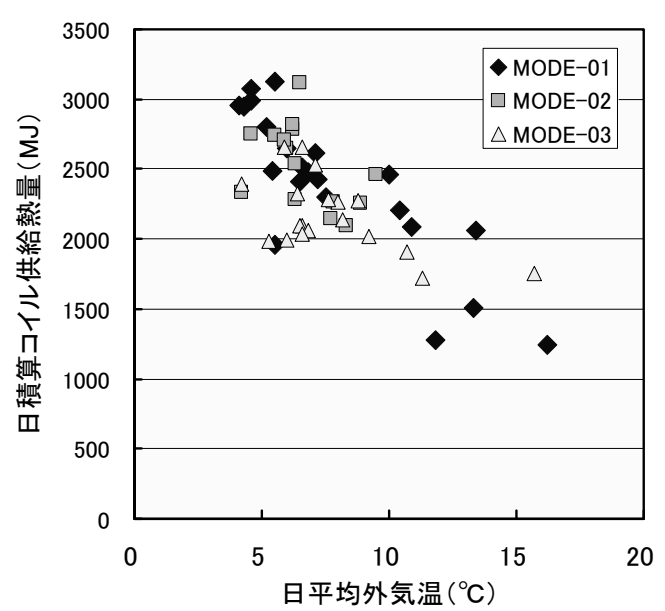

図 8 外気温度とコイル供給熱量との関係

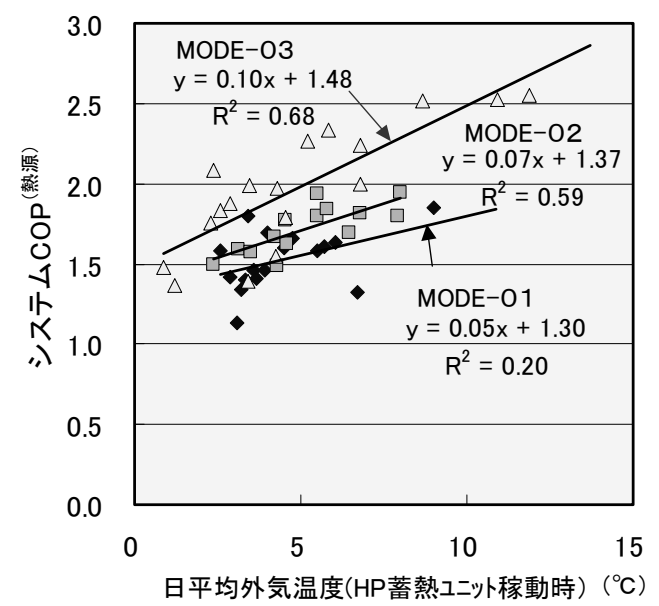

図 9 外気温度とシステムCOP(熱源) との関係

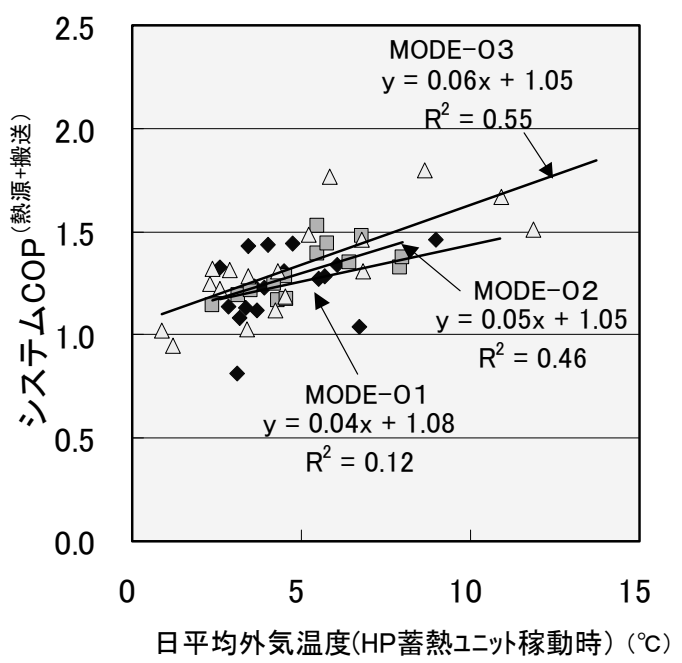

図 10 外気温度とシステムCOP(熱源+般送) との関係

2）菊田弓沙，絵内正道，羽山広文，森太郎：簡易予測制御を適用した躯体蓄熱シ ステムに関する研究，日本建築学会環境系論文集 No. 599, pp. 95-102, 2006.01

3）三浦寿幸, 小池浄一, 栗木茂: 夜間電力を利用した躯体蓄熱方式一の設備改修 身体蓄熱を試夕た外断熱建物の熱環境性状と運転実績 その 5 , 日本建築学会 大会梗概集 環境工学II， pp. 1289-1290，2006.09

4）三浦寿幸, 小池浄一, 栗木茂: 暖房運転方法とシステム成績係数 躯体蓄熱を 試みた外断熱建物の熱環境性状と運転実績 その 6 , 日本建築学会大会梗概集 環境工学 II, pp. 1049-1050, 2007.09

[2015 年 10 月 7 日原稿受理 2016 年 3 月 1 日採用決定］ 